\title{
ВПЛИВ НЕЙРОПЛАСТИЧНОСТІ НЕРВОВОЇ СИСТЕМИ НА РОЗВИТОК ОСОБИСТОСТІ У ПІДЛІТКОВОМУ ВІЩІ
}

\author{
Вікторія Гречуха \\ магістр психології, практичний психолог, керівник психологічного клубу \\ «Пізнавальник» \\ 08131, Україна, Київська обл., с. Софіївська Борщагівка, вул. Боголюбова, 40 \\ 230924v@gmail.com, https://orcid.org/0000-0002-0760-9447
}

\author{
Дарія Отич \\ кандидат психологічних наук, доцент кафедри загальної і соціальної психології та \\ психотерапії \\ Національний педагогічний університет імені М. П. Драгоманова \\ 01601, Україна, м. Київ, вул. Пирогова, 9 \\ d.d.otych@npu.edu.ua, https://orcid.org/0000-0002-6827-9832
}

\begin{abstract}
Анотація
Сучасний підхід до виховання підлітків не враховує специфіки переживання підлітками власних змін саме на цьому етапі розвитку суспільства - він сповнений суперечностей та виступає наслідком нашого нерозуміння, невпевненості та конфліктності: ми в рівній мірі то перебільшуємо ступінь особистісної зрілості підлітків, то применшуємо іiі. У нашому суспільстві 20-літніх людей, які скоїли злочин, судять за усією суворістю закону, тому що вони достатньо дорослі, щоб відповідати за свої вчинки. Водночас діє заборона на продаж алкогольних напоїв людям, які молодші за 21 рік, тому що їх організм ще не зрілий. В результаті у суспільства відсутнє чітко сформоване розуміння про те, яким чином ставитися до людей цієї вікової категорії. Нам необхідно переглянути ставлення до підліткового віку. На щастя, протягом останніх двох десятиліть спостерігається значне зростання інтересу до вивчення підліткового віку. Метою статті є теоретичний аналіз наукових досліджень щодо впливу нейропластичності нервової системи на становлення особистості у підлітковому віці. Завдання дослідження полягали: у виявленні психологічних особливостей розвитку особистості у підлітковому віці; в аналізі психофізіологічних особливостей розвитку нервової системи підлітків; у визначенні ролі нейропластичності нервової системи у особистісному розвитку підлітків. У статті поєднаний досвід вчених, що вивчають підлітковий вік. Загальний підсумок: підлітковий вік як життєвий етап трансформувався, і це потребує радикального перегляду способів виховання сучасних підлітків, їхнього навчання та відношення до них суспільства. Виявлена тенденція до зростання кількості досліджень психологічного розвитку підлітків: актуальним є питання про те, чому звичні психологопедагогічні методи не працюють та як потрібно змінити практичну роботу психолога саме 3 сучасними підлітками задля досягнення ефекту. Проведений теоретичний аналіз останніх наукових даних дозволить привернути увагу до специфіки розвитку нервової системи у підлітковий період. Знання про це дозволять підібрати найбільш оптимальні способи взаємодії з особами підліткового віку і полегшити переживання ними складного та емоційнонасиченого життєвого етапу.
\end{abstract}


Ключові слова: підліток, підлітковий вік, нейропластичність, саморегуляція, сензитивний період.

\section{Вступ}

Процеси, які відбуваються у сучасному суспільстві, зумовлюють зміщення вікових етапів. Саме тому, наразі, психологи говорять про трансформацію підліткового віку як важливого життєвого етапу. Сьогодні тривалість підліткового періоду є найтривалішою в історії людства. Отже,виникає потреба радикального перегляду способів виховання сучасних підлітків, їхнього навчання та ставлення до них суспільства. Водночас зросли кількість $\mathrm{i}$ якість знань про розвиток підлітків: ми можемо відповісти на запитання, чому наші звичні методи навчання, виховання та психологічного впливу не працюють, яким чином потрібно змінити практику поведінки поряд 3 підлітками та які психолого-педагогічні заходи $\epsilon$ ефективними на сьогоднішній день.

Мета дослідження: здійснити теоретичний аналіз наукових досліджень щодо впливу нейропластичності нервової системи на становлення особистості у підлітковому віці. Завдання дослідження: 1) виявити психологічні особливості розвитку особистості у підлітковому віці; 2) проаналізувати фізіологічні особливості розвитку нервової системи підлітків; 3) визначити роль нейропластичності нервової системи у особистісному розвитку підлітків.

\section{Методи дослідження}

Для вивчення особливостей впливу нейропластичності нервової системи підлітків на розвиток їхньої особистості було застосовано теоретичні методи дослідження. Зокрема, для виявлення психологічних особливостей особистісного розвитку підлітків було здійснено аналіз психолого-педагогічної літератури. Для уточнення змісту й сутності психологічних феноменів був проведений аналіз базових понять дослідження. Використання методів причинно-наслідкового аналізу досліджуваних феноменів дозволило виявити специфіку взаємозв'язку нейропластичності нервової системи підлітків (і головного мозку, зокрема) 3 їхнім особистісним розвитком. Отримані результати були систематизовані й узагальнені.

\section{Результати та дискусії}

На початку XX ст. природня незрілість підлітків пояснювалась гормональним сплеском у молодому організмі. Вважалося, що до кінця дитячого віку процес розвитку головного мозку в цілому завершується. Однак, нові дослідження (Дженсен, 2019) вказують на те, що його формування продовжується до 20-ти років та більше. Сьогодні в якості причини називають незрілість кори великих півкуль головного мозку. Зараз достеменно відомо, що у період статевого дозрівання та приблизно до 20-ти років у структурі та функціонуванні нервової системи і головного мозку, зокрема, відбуваються значні системні зміни.

Це не означає, що нервова система чи головний мозок підлітка є неповноцінними. Психологи наголошують, що нервова система у осіб підліткового віку продовжує активно розвиватись, зумовлюючи особливі психічні процеси та стани. Підлітковий вік - це життєвий етап, коли молода людина буває менш зрілою, ніж чим коли вона досягає віку повної дієздатності.

Останні наукові дослідження доводять, що варто переглянути ставлення до 
підліткового віку. Необхідність такого перегляду полягає в тому, що змінюється тривалість означеного вікового періоду. Цей життєвий етап, що колись займав лише декілька років, зараз став більш тривалим. 3 одного боку, пубертатний період починається раніше, а, 3 іншого - все більше затягується перехід молодих людей до етапу, коли вони будують кар'єру, створюють власну сім'ю та стають фінансово незалежними. Іншими словами, початок періоду статевого дозрівання наступає у сучасних дітей раніше, ніж будь-коли в історії, але вони потребують більше часу, щоб подорослішати. Ось чому спеціалісти говорять, що підлітковий вік починається з біології та закінчується соціологією. Наразі перехід від дитинства до дорослого життя займає близько 15-ти років.

Однак, найвагомішою причиною переглянути методи виховання наступного покоління є сучасні дослідження нервової системи. Особливу увагу серед них привертають ті, що спрямовані на вивчення структур головного мозку підлітків (Хомская, 2019): підлітковий вік $\epsilon$ періодом величезної нейропластичності. Нейропластичність - це здатність людського мозку до змін під впливом досвіду.

Будь-який процес навчання має провокувати стійкі зміни у головному мозку людини. Головний мозок у підлітковому віці є більш пластичним у порівнянні не тільки з дитинством, але й $з$ наступним періодом зрілості. Фактично, підлітковий вік є останнім періодом у розвитку, коли головний мозок має підвищену здатність до змін. Одна з причин, чому 3 психологічними проблемами краще розбиратися у юності, ніж у дорослому віці, полягає в тому, щоб з мірою дорослішання ці проблеми перетворюються у сталі психічні механізми.

Пластичність головного мозку передбачає, що зміни можуть відбуватися не тільки у кращий, але й у гірший бік. Тобто, нейропластичність робить підлітковий вік періодом неймовірних можливостей, i, в той самий час - величезного ризику. Якщо підліток потрапляє в позитивне оточення, то в нього все буде складатися добре. Проте, і в несприятливому оточенні вплив на підлітка також буде сильним та стійким. Тому дуже важливо у цей період запропонувати підліткам досвід, що буде стимулювати їхній позитивний розвиток, здійснювати відповідну психологічну профілактику та корекцію негативних явищ психічного розвитку, а також відокремити їх від негативного досвіду, який може зашкодити становленню особистості (Булах, 2003; Dammann \& Поліщук, 2020).

Новий підхід до вивчення підліткового віку пояснює чому цей вік $є$ найбільш вразливим періодом у житті людини, а також чому саме на цьому етапі молоді люди більшою мірою, ніж раніше, схильні до неадекватної поведінки, важче долають психологічні труднощі та вступають у доросле життя. Зміни у структурі головного мозку роблять молодих людей більш емоційно нестабільними. Ці зміни починаються у головному мозку набагато раніше, ніж підвищується здатність людини контролювати свої думки, емоції та дії, тобто формується сукупність навичок, яка у психології отримала назву «саморегуляція». Існує часовий проміжок між активацією систем мозку, що стимулює емоції та імпульсивну поведінку, та розвитком систем, які дозволяють ці емоції та поведінку контролювати. I чим більша тривалість цього періоду дисбалансу, тим вищий ризик виникнення різноманітних проблем, таких як депресія, алкогольна та наркотична залежність, ожиріння, агресивна та інша неадекватна поведінка (Бушай, 2000; Dammann \& Поліщук, 2020; Реан, 2003).

Хоча підлітковий вік в цілому є періодом підвищеної вразливості, одні молоді люди переживають його легше, ніж інші.

Здатність до саморегуляції $\epsilon$, ймовірно, єдиним важливим чинником, що визначає академічні досягнення, психічне здоров'я та успіх у соціумі. Вміння тримати під контролем 
думки, почуття та дії захищає від різних психічних розладів, сприяє розвитку більш якісних міжособистісних стосунків та стимулює досягнення у навчанні та роботі. Цілий ряд досліджень (Кириченко, 2001; Стейнберг, 2017) довів, що молоді люди з високим рівнем саморегуляції завжди більш успішні: вони краще навчаються у школі, їх більше люблять однокласники, вони 3 меншою вірогідністю потрапляють у неприємності та $\epsilon$ менш схильними до психологічних проблем. Саме тому головною задачею особистості у підлітковому віці є розвиток власної саморегуляції.

Системи мозку, що керують саморегуляцією, характеризуються підвищеним ступенем змінюваності у підлітковому віці. Таким чином, цей період є сприятливим моментом для втручання, щоб стимулювати позитивний розвиток та захистити підлітків від небезпечних ситуацій та не наражати на ризик порушення нормального розвитку регуляторних систем. Здатність до змін включає в себе і великі ризики, оскільки у ці періоди підвищеної чутливості головний мозок є більш уразливим перед фізичним (споживання алкоголю, наркотиків, шкідливе середовище) або психологічним впливом (стреси або емоційні травми) (Наказава, 2020).

Пластичність процесів змін визначає здатність головного мозку змінюватися впродовж його розвитку, коли значним чином трансформується його анатомія. Деякі з цих змін включають розвиток або втрату клітин мозку, але найбільш важливі стосуються «зв’язків» у мозку, тобто того, як трильйони нейронів взаємодіють між собою. Головний мозок функціонує ефективно завдяки тому, що нейрони з'єднані між собою вибірково, а не всі разом. При народженні людина має найбільшу кількість нейронів, порівняно з іншими етапами життя. Упродовж перших років життя в головному мозку не формується багато нових нейронів, проте створюються мільярди зв'язків між ними. Це масштабний процес. Створення міжнейронних поєднань (синапсів) у ранньому віці буває надлишковим. Частиною еволюційної пластичності мозку є ліквідація надлишкових синаптичних зв'язків так званий прунінг. В областях головного мозку, які контролюють когнітивні функції більш високого рівня, наприклад, здатність до прийняття складних рішень, у підлітковому віці відбувається найбільш активний процес прунінгу. Ці системи головного мозку досягають у людини остаточної зрілості близько 20 років. Саме тому здатність людини до виконання когнітивних функцій вищого рівню формується під впливом досвіду, отриманого у підлітковому віці (Дженсен, 2019; Свааб, 2019).

Також у період статевого дозрівання мозок підлітка зазнає радикальних змін під впливом гормонів статевого дозрівання - тестостерона та естрогена. Рівень цих гормонів значною мірою збільшується у пубертатний період. Вони впливають на будову мозку, хімічно змінюючи існуючу структуру нейронних зв'язків. Статеві гормони забезпечують мієлінізацію, стимулюють розвиток нових нейронів та сприяють процесу синаптичного прунінгу. В пубертатний період мозок людини стає більш сприйнятливим до будь-якого зовнішнього впливу, позитивного або негативного. Це викликає більшу пластичність мозку (Дженсен, 2019; Роджерс, 2017; Токарева, Шамне \& Макаренко, 2014).

Формування мозку відбувається поступово. Різні системи мозку розвиваються у різний час та мають різні періоди еволюційної пластичності, які називають «сензитивними періодами». Системи мозку, які відповідають за базові здатності людини, наприклад, здатність бачити, чути, навчатися, характеризуються ранніми та короткими сензитивними періодами, зазвичай упродовж декількох перших місяців життя. Системи мозку, що 
регулюють здатності більш високого рівня, наприклад, мовленнєві навички або емоційну прихильність до батьків, мають більш пізній та тривалий період пластичності, як правило, перші роки життя. Системи головного мозку, які контролюють здатності вищого рівня, наприклад, логічного мислення, планування, саморегуляції, мають набагато триваліший період пластичності. Багато аспектів цих систем набувають повної зрілості лише у віці 20-25 років (Фопель, 2008; Хомская, 2019).

Раннє формування базових систем мозку в основному визначається біологічною програмою, записаною у нашому генетичному коді, яка починає реалізовуватися, коли дитина ще знаходиться в утробі матері та продовжує реалізовуватися в перші місяці життя.

Системи головного мозку, що контролюють більш складні навички, мають більш високу здатність до змін, тому відмінності у зовнішньому досвіді значною мірою впливають на їхній розвиток та остаточне формування. Розвиток цього типу здібностей суттєво залежить від особливостей оточуючого середовища, в якому відбувається формування цих систем мозку.

На різних етапах розвитку особистості однаковий досвід впливає на різні зони головного мозку в залежності від того, які з них в цей момент найбільш чутливі до змін. Наприклад, у ході дослідження сексуального насильства виявилося, що зона головного мозку, яка реагувала на подібний випадок, відрізнялася в залежності від віку, в якому це відбулося. Сексуальне насильство в ранньому дитинстві впливало на гіппокамп - частину головного мозку, яка бере участь у механізмах консолідації пам'яті. Сексуальне насильство у підлітковому віці впливало на префронтальну кору - частину головного мозку, особливо пластичну в цьому віці та відповідальну за самоконтроль (Лурия, 2019).

Для виховання людей, які здатні усвідомлювати потреби інших, їхню мотивацію та наміри, будувати та здійснювати плани, прогнозувати довготривалі наслідки своїх дій, контролювати власну поведінку, емоції та думки, необхідно забезпечити правильне стимулювання в той час, коли системи мозку, що регулюють ці здібності, є пластичними, і особливо зосередитися на тих періодах, коли здатність мозку до змін під впливом досвіду $є$ найбільш високою. Тобто, підлітковий вік має велике значення не тільки тому, що головний мозок у цей період є пластичним. Не менш важливо, які саме області мозку є пластичними. У підлітковому віці відбувається особливо активний розвиток зон мозку, що регулюють відчуття насолоди, те, як людина сприймає оточуючих, а також іiі здатність до вияву самоконтролю. Ці три системи мозку - підкріплююча, система міжособистісних відносин та регуляторна - $\epsilon$ основними областями, в яких відбуваються зміни в підлітковому періоді. Їх можна вважати трьома основними факторами розвитку головного мозку у підлітковому періоді: вони $є$ найбільш сприятливими до стимулювання, і в той самий час - найбільш уразливими до негативного впливу (Лурия, 2019; Фабер \& Мазлиш, 2016).

Також саме у підлітковому віці починають розвиватися серйозні психічні розлади. В підлітковому віці мозок є особливо чуттєвим до стресу. Серйозні розлади психіки починають розвиватися десь 314 років. Різні розлади, такі як розлади настрою (депресія, біполярний афективний розлад); розлади, пов'язані із зловживанням алкоголю, наркотична залежність; тривожні розлади (такі як обсесивно-компульсивний розлад, панічний розлад та генералізований тривожний розлад); більшість розладів імпульсивного контролю (розлади поведінки та опозиційно-викликаючий розлад); розлади харчової поведінки (такі як анорексія, булімія; шизофренія) $з$ найбільшою імовірністю починають виявлятися в період 
від 10 до 25 років. 3 іншого боку, вірогідність того, що вони можуть виявитися у більш пізньому віці, мінімальна (Гурьева, 2007).

Отже, пластичність головного мозку може відіграти як позитивну, так і негативну роль. Це відповідає думці, що позбавлятися психологічних негараздів, щойно вони виникли, легше, ніж коли вони вже закріпилися. Оскільки мозок підлітків є більш пластичним, надзвичайно важливо у цьому віці впроваджувати профілактично-корекційні заходи щодо впливу негативних чинників, які можуть спричинити порушення психічного здоров’я.

\section{Висновки}

Підлітковий вік - це період, коли молода людина набуває системи навичок та здібностей, які необхідні ій для самостійного життя. У цей фінальний період підготовки до дорослого життя у молодої людини є час пізнати все, що їй потрібно знати, до того, як увійти у самостійне життя, і тому вона, як губка, вбирає будь-яку інформацію. Саме тому, у підлітковому віці мозок налаштований помічати абсолютно все, що відбувається навкруги, навіть, якщо ми свідомо не звертаємо на це уваги. По мірі того, як підлітковий вік наближається до завершення, а необхідні знання та навички вже отримані, мозок починає ефективно використовувати власний ресурс. Пластичність мозку надзвичайно важлива у період розвитку, але не варто забувати, що будь-яке середовище несе в собі не тільки можливості, а й небезпеки. Ще ніколи в історії цей період можливостей та небезпек не був більш тривалим, і тому, насьогодні, підлітковий вік має особливе значення.

Підлітковий вік складає конкуренцію віку «від нуля до трьох» 3 точки зору нейропластичності. Інвестувати у розвиток дітей на ранньому етапі життя надзвичайно важливо, але, якщо на цьому зупинитися до того часу, коли ці діти перейдуть до підліткового віку, більша частина «попередніх інвестицій» не збережеться. Дуже важливо, щоб вік немовляти та ранній вік стали для дитини здоровим життєвим стартом, але все ж таки ранній розвиток є саме фундаментом, на якому у підлітковому віці будується подальший розвиток головного мозку людини як центральне утворення нервової системи.

Підлітковий вік - це друга та фінальна стадія розвитку головного мозку, яка характеризується підвищеною нейропластичністю. Вірогідно, що остання реальна можливість спрямувати підлітків на шлях позитивного здорового розвитку й очікувати, що наш вплив буде мати стійкий та довготривалий ефект. Для того, щоб зрозуміти, яким чином динаміка розвитку головного мозку впиває на все життя загалом, необхідно активно досліджувати механізми мозкової нейропластичності.

При досягненні підліткового віку мозок зберігає свою пластичність, а біологічно запрограмовані зміни у пубертатному періоді відчиняють це вікно пластичності ще ширше. Беручи це до уваги, більш тривалий перехід до дорослого життя є більш корисним, ніж вважають більшість батьків, педагогів та психологів. Ті молоді люди, яким пощастило подовжити свій підлітковий вік, зможуть скористатися цим повною мірою, якщо в оточуючому середовищі знайдуть можливості для позитивного стимулювання та зможуть уникнути негативного впливу. Нещодавні дослідження свідчать про те, що вища освіта сприяє розвитку вищих когнітивних здібностей завдяки поліпшенню структури білої речовини мозку більшою мірою, аніж це відбувається в результаті біологічного дорослішання. Імовірно, це і є основною перевагою зростання тривалості переходу підлітків до дорослого життя. 
Перспективи подальшого дослідження полягають у порівняльному вивченні особливостей нейропластичності мозку дітей молодшого шкільного та підліткового віку.

\section{Література}

1. Булах, І.С. (2003). Психологія особистісного зростання підлітка: Монографія. Київ : НПУ імені М.П. Драгоманова.

2. Бушай, I.M. (2000). Психологічні особливості розвитку «Я-образу» акцентуйованих підлітків. Творча спадщина Г.С.Костюка та сучасна психологія. До 100-річчя від дня народження академіка Г.С.Костюка. Матеріали III з’їзду Товариства психологів України. Київ.

3. Гурьева, В.А. (2007). Клиническая и судебная подростковая психиатрия. Москва : Медицинское информационное агенство.

4. Dammann, G., \& Поліщук, В. (2020). Маленький принц - самогубство серед підлітків. Психосоматична медицина та загальна практика 5, 2. Київ : Національний медичний університет імені О.О. Богомольця. Режим доступу: https://uk.e-medjournal.com/index.php /psp/article/view/240\#author-2

5. Дженсен, Фрэнсис Э. (2019). Мозг подростка. Москва : Бомбора.

6. Кириченко, Т.В. (2001). Психологічні механізми саморегулящії поведінки підлітків (автореф. дис. канд. психол. наук). Київ : Нац. пед. ун-т ім. М.П.Драгоманова.

7. Лурия, А.Р. (2019) Высшие корковые функции человека. Санкт-Петербург : Питер.

8. Наказава, Донна Джексон (2020). Осколки детских травм. Москва : Бомбора.

9. Реан, А.А. (2003). Психология подростка. Полное руководство. Санкт-Петербург : Прайм-ЕВРОЗНАК

10. Роджерс, Карл Р. (2017). Становление личности. Взгляд на психотерапию. Москва : ИОИ.

11. Свааб, Д.Ф. (2019). Наш творчий мозок. Харків : Клуб Сімейного Дозвілля.

12. Стейнберг, Лоуренс. (2017). Переходный возраст. Москва: Манн, Иванов и Фербер.

13. Токарева, Н.М., Шамне, А.В., \& Макаренко, Н М. (2014). Сучасний підліток у системі психолого-педагогічного супроводу: монографія. Кривий Ріг.

14. Фабер, А., \& Мазлиш, Э. (2016). Как говорить, чтобы подростки слушали. Москва.

15. Фопель, К. (2008). На пороге взрослой жизни. Планирование жизни. Решение проблем. Сотрудничество. Москва : Генезис.

16. Хомская, Е.Д. (2019). Нейропсихология: учебник для вузов. 3-е изд. Санкт-Петербург : Питер.

\section{References}

1. Bulakh, I.S. (2003). Psykholohiia osobystisnoho zrostannia pidlitka [Psychology of personal growth of the teenager]: Monohrafiia. Kyiv : NPU imeni M.P. Drahomanova [in Ukrainian].

2. Bushai, I.M. (2000). Psykholohichni osoblyvosti rozvytku «Ia-obrazu» aktsentuiovanykh pidlitkiv [Psychological features of the development of "I-image" of accentuated adolescents]. 
Tvorcha spadshchyna H.S.Kostiuka ta suchasna psykholohiia. Do 100-richchia vid dnia narodzhennia akademika H.S.Kostiuka. Materialy III zizdu Tovarystva psykholohiv Ukrainy. Kyiv [in Ukrainian].

3. Gurjewa, W.A. (2007) Klinicheskayaa i sudebnaya podrodtkowaya psihiatriya. [Clinical and forensicadolescent psychiatry] Moskwa : Medizinskoye informazionnoye agenstwo [in Russian].

4. Dammann, G., \& Polishchuk, V. (2020). Malenkyi prynts - samohubstvo sered pidlitkiv [The Little Prince is a suicide among teenagers.]. Psykhosomatychna medytsyna ta zahalna praktyka 5, 2. Kyiv: Natsionalnyi medychnyi universytet imeni O.O. Bohomoltsia. Rezhym dostupu: https://uk.e-medjournal.com/index.php/psp/article/view/240\#author-2 [in Ukrainian].

5. Dzhensen, Francis E. (2019). Mozg podrostka [Teen brain]. Moskwa : Bombora [in Russian].

6. Kyrychenko, T.V. (2001). Psykholohichni mekhanizmy samorehuliatsii povedinky pidlitkiv [Psychological mechanisms of self-regulation of adolescent behavior] (avtoref. dys. kand. psykhol. nauk). Kyiv : Nats. ped. un-t im. M.P.Drahomanova [in Ukrainian].

7. Luriya, A.R. (2019). Vysshyie korkovyie funktsii cheloveka [Higher cortical functionsof a person]. Sankt-Peterburg : Piter [in Russian].

8. Nakazawa, Donna Djekson. (2020). Oskolki detskih trawm [Fragments of childhood trauma]. Moskwa : Bombora [in Russian].

9. Rean, A.A. (2003). Psikhologiya podrostka. Polnoe rukovodstvo [Adolescent psychology. Complete guide]. Sankt-Peterburg : Prajm-EVROZNAK [in Russian].

10. Rodgers, K. (2017). Stanovlenie lichnosti. Wzglyad na psichoterapiyu. [Personality formation]. Moskwa: IOI [in Russian].

11. Svaab, D.F. (2019). Nash tvorchyi mozok [Our creative brain]. Kharkiv : Klub Simeinoho Dozvillia. [in Ukrainian].

12. Steinberg, Laurence. (2017). Perehodnyj wozrast [Transitional age]. Moskwa : Mann. Iwanow and Feber [in Russian].

13. Tokareva, N.M., Shamne, A.V., \& Makarenko, N.M. (2014). Suchasnyi pidlitok u systemi psykholoho-pedahohichnoho suprovodu [The modern teenager in the system of psychological and pedagogical support]: monohrafiia. Kryvyi Rih [in Ukrainian].

14. Faber, A., \& Mazlish, E. (2016). Kak goworit, chtoby podrostki clushali [How to talk so that teenagers listen]. Moskwa [in Russian].

15. Fopel, K. (2008). Na poroge wzrosloj zhizni. Planirowaniye zhizni. Resheniye problem. Sotrudnichestwo [On the verge of adulthood]. Moskwa : Genesis [in Russian].

16. Homskaja, E.D. (2019). Neuropsihologiya: uchebnik dlya wyzow. [Neuropsychology]. SanktPeterburg : Piter [in Russian]. 
THE INFLUENCE OF NEUROPLASTICITY OF THE NERVOUS SYSTEM ON THE DEVELOPMENT OF PERSONALITY IN ADOLESCENCE

Viktoriia Grechukha

Master of Psychology, practical psychologist, Head of Psychological Club "Poznavatel"

40, Bogolyubova Str., village Sofiyivska Borshchahivka, Kyiv region, Ukraine, 08131

230924v@gmail.com, https://orcid.org/0000-0002-0760-9447

\author{
Dariia Otych \\ PhD in Psychology, Associate Professor of the Department of General and Social Psychology \\ and Psychotherapy \\ National Pedagogical Dragomanov University \\ 9, Pyrohov Str., Kyiv, Ukraine, 01601 \\ d.d.otych@npu.edu.ua, https://orcid.org/0000-0002-6827-9832
}

\begin{abstract}
The modern approach to adolescent education is a consequence of our misunderstanding, insecurity and contradictions: we equally exaggerate the degree of personal maturity of adolescents, then we underestimate it. In our society 20 -year-old people who have committed a crime are judged to the fullest extent oh the law, because they are old enough to take responsibility for their actions. At the same time, there is a ban on the sale of alcoholic beverages to people under the age of 21 , because their body is not yet mature. As a result, society has no understanding, how to treat people of this age category. We need to rethink our attitude towards adolescence. Fortunately, over the past decades, there has been a significant increase in scientific interest in the study of adolescence. The aim of the article is to describe the results of theoretical analysis of scientific research on the impact of neuroplasticity of the nervous system on the formation of personality in adolescence. The aim of the article is a theoretical analysis of scientific research on the influence of neuroplasticity of the nervous system on the formation of personality in adolescence. The objectives of the study were: to identify the psychological characteristics of personality development in adolescence; in the analysis of psychophysiological features of the development of a nervous system of teenagers; in determining the role of neuroplasticity of the nervous system in the personal development of adolescents. The article combines the experience of scientists who study the adolescence. Overall result adolescence as a stage in life requires a radical revision of the methods of education of modern adolescence, their teaching and society`s attitude towards them. It was revealed a tendency towards an increase in the number of studies of psychological and pedagogical methods do not work and how it is necessary to change the practical work of a psychologist with modern adolescence is relevant in order to achieve an effect. The conducted theoretical analysis of the latest scientific data will draw attention to the specifics of the development of the brain during adolescence. Knowledge about this will allow choosing the most optimal ways of interacting with adolescence and facilitate their experience of a difficult an emotionally intense life stage.
\end{abstract}

Keywords: teenager, adolescence, neuroplasticity, self-regulation, sensitive period.

Подано 26.08.2020

Рекомендовано до друку 03.09.2020 